\title{
The First Record of Fossil Rubiaceae Wood from Egypt
}

\author{
W. E. El-Saadawi", Mona H. Darwish ${ }^{* *}$, Marwah M. Kamal \\ El-Din* and S. G. Youssef* \\ Botany Department, Faculty of Science, ${ }^{* *}$ Botany Department, \\ Women's College for Science, Arts and Education, Ain Shams \\ University, Cairo, and ${ }^{* * * *}$ Botany Department, Faculty of Science, \\ Benha University, Benha Egypt.
}

\begin{abstract}
A FOSSIL dicot wood specimen is described from the lower Miocene of Gebel El-Khashab Formation in the west of Giza Pyramids, Egypt. Anatomical characters suggest affinities with Rubiaceae. Comment is given on the distribution of Rubiaceae fossil wood in the world particularly Africa.
\end{abstract}

Keywords: Africa, Miocene, Petrified Dicot Wood, Rubiaceous Wood, Xylotomy.

The fossiliferous, west of Giza Pyramids area, is located at latitude $30^{\circ} 05^{`} \mathrm{~N}$ and longitude $30^{\circ} 37^{\circ} \mathrm{E}$ and lies in the northeast of the Western Desert of Egypt to the west of Cairo (Fig. 1). It belongs to Gebel El-Khashab Formation (Issawi et al. 1999) and is of early Miocene age (Said 1962, 1971).

The lithostratigraphic section exposed in the study area appears as vividly coloured sands and gravels. It underlies the Plio-Pleistocene gravel terraces of Sand-ford (Idfu gravels) and overlies the basalt flow. Fossil tree trunks are found in basal beds in places with Scutella remains (Said, 1971). Palaeobotanical works by Schenk (1883), Stenzel (1904), Schuster (1910), Kräusel and Stromer (1924), Kräusel (1939) and Youssef (1993) showed that these trunks belonged to 15 species (13 dicots and 2 monocots) in 8 families namely: Fabaceae ( 3 genera and 3 species), Combretaceae (one genus with 4 species), Moraceae and Arecaceae (one genus with 2 species each) and Anacardiaceae, Ebenaceae, Malvaceae and Sapindaceae (one species each).

The aim of this work, is to give the results of the study of fossil woods collected from the study area. 


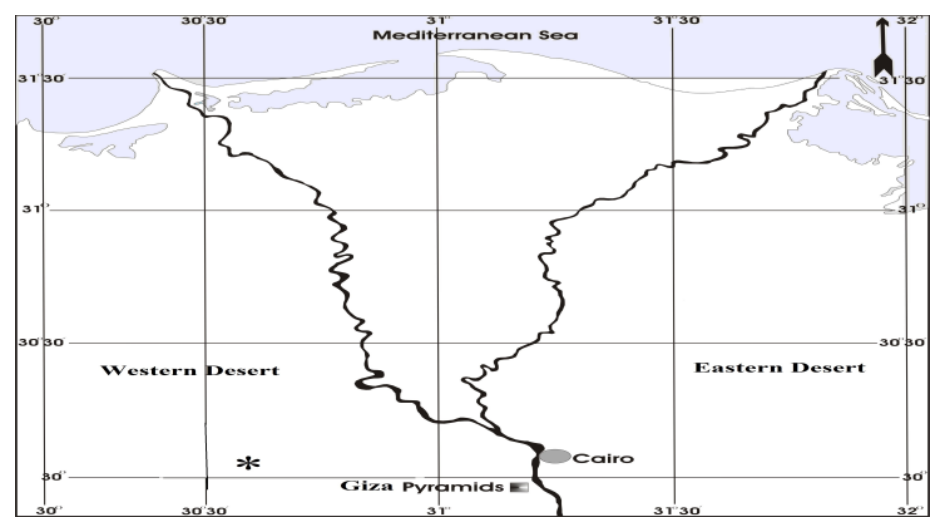

Fig. 1. Map of the northern part of Egypt showing location of the study area (asterisk).

\section{Materials and Methods}

Eighteen fossil wood specimens were collected by Dr. S. Youssef (one of the present authors) and Dr. R. Osman (Prof. of geology) who guided the excursion to the study area. The trunks or loose fragments from which the eighteen specimens were taken vary from $1-20 \mathrm{~m}$ in length and $20-50 \mathrm{~cm}$ in diameter. Section (cross, tangential and radial longitudinal) preparation was after Andrews (1961).

\section{Results}

Careful microscopic investigation using the format of the IAWA List of Features Suitable for Hardwood Identification (IAWA Committee 1989) and consulting references such as Metcalfe and Chalk (1950), Jansen et al. (2002), APG III (2009) and the database available at the web page: http://insidewood.lib.ncsu.edu/description for fossil and modern woods led us to find out that seventeen specimens belonged to three species namely: Bombacoxylon owenii (Malvaceae-Bombacoideae, seven specimens), Terminalioxylon geinitzii (Combretaceae, four specimens) and Terminalioxylon intermedium (Combretaceae, six specimens) that had already been recorded, described and commented upon from many sites in Egypt (Kräusel, 1939; Youssef, 1993; Kamal, El-Din, 2002; El-Saadawi \& Kamal El-Din, 2004; ElSaadawi, et al. 2014 and Kamal El-Din, et al., 2015). It has to be mentioned, however, that $B$. owenii, $T$. geinitzii and T. intermedium are old records to the study area (Kräusel, 1939 and Youssef, 1993). The single remaining specimen no. 6 WGP (W = West, $\mathrm{G}=$ Giza, $\mathrm{P}=$ Pyramids) belonged to Rubiaceae. This is the first record of fossil wood belonging to this family from Egypt ( Kräusel 1939; Dupéron-Laudoueneix \& Dupéron 1995 and Gregory et al., 2009). However, a fossil Rubiaceae fruit had been reported earlier (Kräusel, 1939 and Chandler, 1954) from the Eocene of the country.

Egypt. J. Bot. 56, No. 3 (2016) 
A description of this newly recorded fossil rubiaceous wood together with comments on affinities, distribution and palaeoclimate are given below.

\section{Description, Comparisons and Affinities}

Order: Gentianales

Family: Rubiaceae

Genus and species unnamed (Fig. 2)

Diagnosis: Vessels in radial multiples of $2-8$ (mostly 3-4) and rarely solitary, perforation plates simple and scalariform, intervessel pits vestured; fibers septate; axial parenchyma apotracheal and paratracheal; rays 1-3 (rarely 4) seriate, with multiseriate portion(s) equal in width to uniseriate parts.

Growth rings indistinct. Wood diffuse-porous. Vessels in radial pattern, in radial multiples of 2-8 (mostly 3-4) and rarely solitary, angled in outline, tangential diameter 120-160 $\mu \mathrm{m}$ (mean $140 \mu \mathrm{m}$ ) and radial diameter $100-230 \mu \mathrm{m}$ (mean $180 \mu \mathrm{m}$ ). Mean vessel element length $780 \mu \mathrm{m}$. Vessels / sq. $\mathrm{mm}$ 24-40. Perforation plates simple and scalariform with $\leq 10$ bars, with very oblique end walls. Intervessel pits alternate, opposite and vestured. Tyloses absent. Fibers septate, very thin-walled. Axial parenchyma apotracheal diffuse, diffuse-in-aggregates and scanty paratracheal. Rays 1-3 (rarely 4) seriate, with multiseriate portion(s) equal in width to uniseriate parts, with 1 to over 4 marginal rows.

Note: Fungal hyphae are present in the vessel elements.

Similarities to extant woods

Families with some members that have radial multiples of 4 or more vessels, both simple and scalariform perforation plates, alternate intervessel pitting and septate fibers are Apocynaceae and Rubiaceae of the Gentianales. However, Rubiaceae is distinguished by vestured intervessel pits, $20-40$ vessels/sq. mm, very long vessel elements, diffuse, diffuse-in-aggregates and scanty axial parenchyma, narrow rays, 1-3 rarely 4 seriate with 1 to over 4 uniseriate margins (Metcalfe \& Chalk, 1950 and Jansen et al., 2002). We, therefore, consider this wood's affinities, even in the absence of the RLS, to be with Rubiaceae. In this family, there are two main types of secondary xylem (KoekNoorman, 1977). Type I has fiber-tracheids, apotracheal diffuse, diffuse-inaggregates or banded axial parenchyma, mainly solitary vessels and narrow rays with long uniseriate margins. In type II fibers are septate libriform, axial parenchyma scanty or absent, vessels in radial multiples (2-4 or more) and solitary, rays wider and with a few rows of upright/square ray cells (Jansen, et al., 2002). The west of Giza Pyramids wood specimen has combination of characters from type I as apotracheal diffuse and diffuse-in-aggregates axial 
parenchyma, narrow rays with uniseriate margins and type II as septate fibers, vessels in radial multiples and scanty parenchyma. Family Rubiaceae has three subfamilies, of which subfamilies Cinchonoideae (mainly Tribe Guettardeae) and Rubioideae have wood type I and II in some genera and in species of some genera (Jansen, et al., 2002). The west of Giza Pyramids wood specimen has similarity to the genera of Tribe Guettardeae which have wood type I and II (mainly genus Anthirhea). But, the present fossil wood has septate fibers and these genera do not (Jansen, et al., 2002).

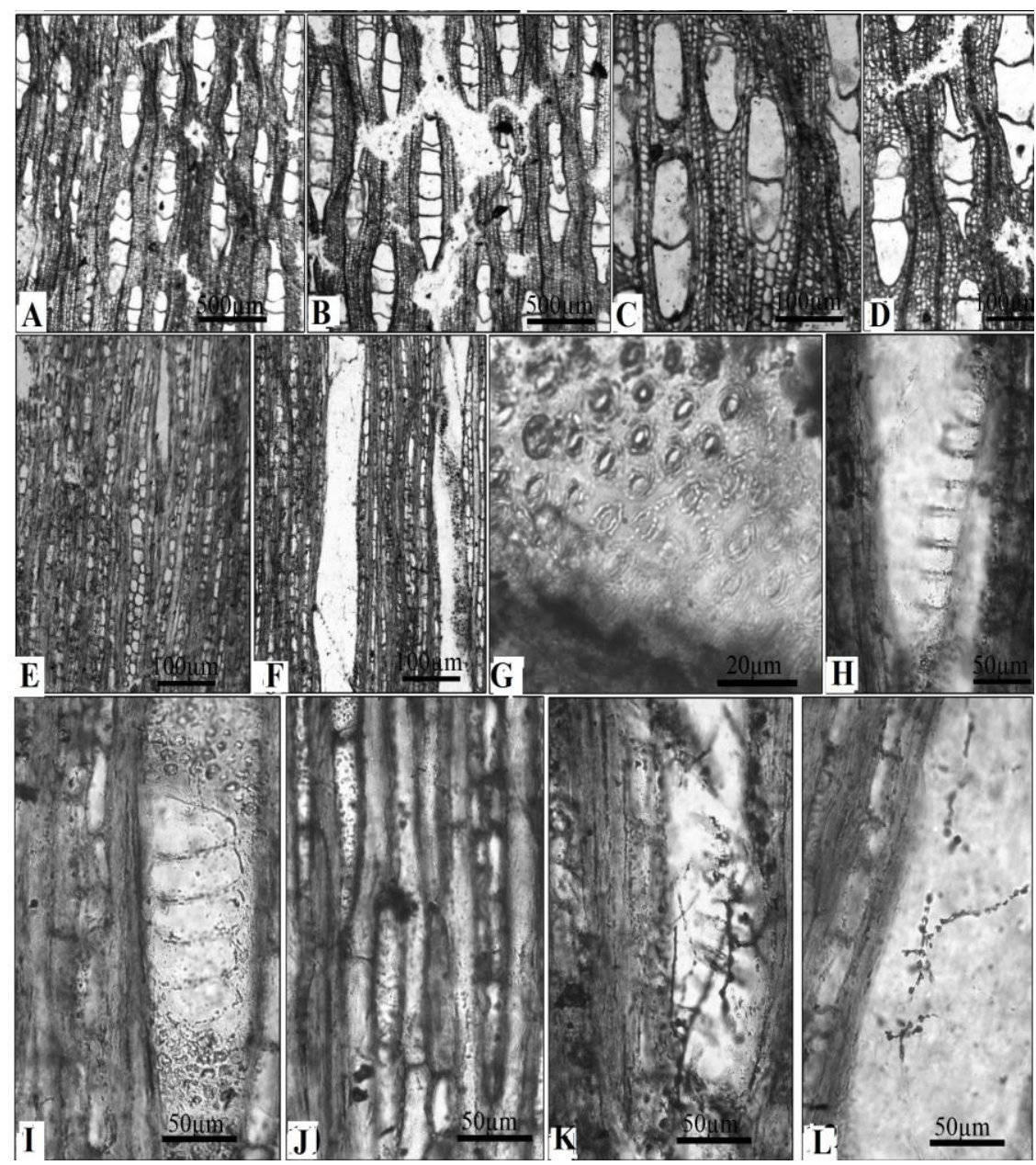

Fig. 2. Fossil rubiaceous wood 6 WGP- A, B: Indistinct growth rings, vessels in radial multiples, TS. - C, D: Diffuse and scanty parenchyma, TS. - E: Rays 1-3 seriate, TLS. - F: Oblique end walls and scalariform perforation plates, TLS. - G: Vestured pits, LS. - H, I: Scalariform perforation plates, LS. - J: Septate fibers, TLS. - K, L: Fungal hyphae in vessel element, LS. - Scale bars: $A, B=500 \mu \mathrm{m} ; C, D, E, F=100 \mu \mathrm{m} ; G=20 \mu \mathrm{m} ; \mathrm{H}, \mathrm{I}, \mathrm{J}, \mathrm{K}, \mathrm{L}=50 \mu \mathrm{m}$.

Egypt. J. Bot. 56, No. 3 (2016) 
Comparisons with other fossil woods

There are over ten other fossil woods attributed to Rubiaceae worldwide as presented in Table (1) below.

TABLE 1. The distribution of fossil Rubiaceae woods in the world. based onDupéron-Laudoueneix \& Dupéron (1995) Gregory et al. (2009) Insidewood (2016). (\# = name seen in Koeniguer (1975) but reference not in his bibliography; perhaps error for Mitragynoxylon gevini? Gregory et al., 2009), $\wedge$ = reported by Dechamps (1976) however, without descriptions or illustrations (Gregory et al. 2009)). * = description available.

\begin{tabular}{|c|c|c|c|}
\hline \multirow[t]{2}{*}{ Fossil Rubiaceae wood taxa } & \multicolumn{3}{|l|}{ Continents } \\
\hline & Africa & Asia & Europe \\
\hline Canthium omoensis $*$ & $\begin{array}{l}\text { Ethiopia } \\
\text { (Pliocene) }\end{array}$ & & \\
\hline $\begin{array}{l}\text { Canthiumoxylon } \\
\text { neyveliensis }\end{array}$ & & $\begin{array}{l}\text { India (age } \\
\text { unknown) }\end{array}$ & \\
\hline $\begin{array}{l}\text { Grangeonixylon } \\
\text { apocynorubioides } *\end{array}$ & & & France (Eocene) \\
\hline G. danguense * & & & France (Eocene) \\
\hline Mitragynoxylon gevini $*$ & $\begin{array}{l}\text { Algeria } \\
\text { (Oligocene } \\
\text { and Miocene) }\end{array}$ & & \\
\hline Naucleoxylon gevini \# & $\begin{array}{l}\text { North Africa } \\
\text { (Tertiary) }\end{array}$ & & \\
\hline N. spectabile & & $\begin{array}{l}\text { Java } \\
\text { (Pliocene) }\end{array}$ & \\
\hline Rothmannia aethiopica $*$ & $\begin{array}{l}\text { Ethiopia } \\
\text { (Pliocene) }\end{array}$ & & \\
\hline R. omoensis * & $\begin{array}{l}\text { Ethiopia } \\
\text { (Pliocene) }\end{array}$ & & \\
\hline R. urcelliformis ${ }^{\wedge}$ & $\begin{array}{l}\text { Ethiopia } \\
\text { (Pliocene) }\end{array}$ & & \\
\hline Rubioxylon naucleoides & & & Austria (Oligocene) \\
\hline R. vincent $*$ & $\begin{array}{l}\text { Chad } \\
\text { (Pliocene) }\end{array}$ & & \\
\hline cf. $R$. vincenti $*$ & $\begin{array}{l}\text { Ethiopia } \\
\text { (Miocene) }\end{array}$ & & \\
\hline
\end{tabular}

Out of the species listed, above, in Table 1 we have the descriptions of only the 8 asterisked species. Furthermore, Grangeonixylon apocynorubioides and G. danguense are not unequivocally assigned to Rubiaceae [probably Apocynaceae (Gregory, et al., 2009)]. Therefore, comparisons, between only 6 fossil woods of Rubiaceae (all African by chance), are made with the present fossil wood as comes in Table 2 below. 
TABLE 2. Comparisons between the six African fossil wood species of Rubiaceae after Insidewood (2016) and the present Rubiaceae wood.

\begin{tabular}{|c|c|c|c|c|c|c|c|}
\hline Characters & $\begin{array}{l}\text { Canthium } \\
\text { omoensis }\end{array}$ & $\begin{array}{c}\text { Mitragynoxy } \\
\text { lon gevini }\end{array}$ & $\begin{array}{c}\text { Rothmannia } \\
\text { aethiopica }\end{array}$ & $\begin{array}{c}R . \\
\text { omoensis }\end{array}$ & $\begin{array}{c}\text { Rubioxylon } \\
\text { vincenti }\end{array}$ & $\begin{array}{c}\text { cf. } R \text {. } \\
\text { vincenti }\end{array}$ & $\begin{array}{c}\text { The } \\
\text { present } \\
\text { wood }\end{array}$ \\
\hline $\begin{array}{c}\text { Growth } \\
\text { rings }\end{array}$ & $\begin{array}{l}\text { indistinct } \\
\text { or absent }\end{array}$ & distinct & $\begin{array}{c}\text { indistinct or } \\
\text { absent }\end{array}$ & $\begin{array}{l}\text { indistinct } \\
\text { or absent }\end{array}$ & $\begin{array}{c}\text { indistinct or } \\
\text { absent }\end{array}$ & distinct & $\begin{array}{c}\text { indistinct or } \\
\text { absent }\end{array}$ \\
\hline Wood & diffuse & semi-ring & diffuse & diffuse & semi-ring & semi-ring & diffuse \\
\hline Vessels & - & $\begin{array}{c}\text { in radial } \\
\text { multiples of } \\
4 \text { or more }\end{array}$ & - & $\begin{array}{l}90 \% \\
\text { solitary }\end{array}$ & \begin{tabular}{|c} 
in radial \\
multiples of \\
4 or more
\end{tabular} & - & $\begin{array}{c}\text { in radial } \\
\text { multiples of } \\
4 \text { or more }\end{array}$ \\
\hline $\begin{array}{c}\text { Perforation } \\
\text { plates }\end{array}$ & simple & simple & $\begin{array}{c}\text { simple and } \\
\text { scalariform } \\
\text { from } 10-40 \\
\text { bars }\end{array}$ & \begin{tabular}{|c|} 
simple and \\
scalarifor \\
$\mathrm{m}$ from \\
$10-40$ \\
bars
\end{tabular} & simple & $\begin{array}{c}\text { simple and } \\
\text { scalarifor } \\
\mathrm{m} \text { from } \\
10-40 \\
\text { bars } \\
\end{array}$ & $\begin{array}{c}\text { simple and } \\
\text { scalariform } \\
\text { less than } 10 \\
\text { bars }\end{array}$ \\
\hline $\begin{array}{c}\text { Intervessel } \\
\text { pits }\end{array}$ & \begin{tabular}{|c|} 
scalariform, \\
opposite \\
and \\
alternate
\end{tabular} & alternate & $\begin{array}{l}\text { opposite } \\
\text { and } \\
\text { alternate }\end{array}$ & $\begin{array}{l}\text { scalariform, } \\
\text { opposite } \\
\text { and } \\
\text { alternate }\end{array}$ & alternate & $\begin{array}{l}\text { scalariform, } \\
\text { opposite } \\
\text { and } \\
\text { alternate }\end{array}$ & $\begin{array}{c}\text { alternate, } \\
\text { opposite } \\
\text { and } \\
\text { vestured }\end{array}$ \\
\hline $\begin{array}{c}\text { Vessels / } \\
\text { mm }^{2} \\
\end{array}$ & $20-40$ & $5-20,20-40$ & $5-20$ & $40-100$ & $\leq 5$ & $\leq 5$ & $24-40$ \\
\hline parenchyma & \begin{tabular}{|c|} 
diffuse, \\
diffuse-in- \\
aggregate \\
and \\
scanty \\
\end{tabular} & $\begin{array}{l}\text { diffuse and } \\
\text { diffuse-in- } \\
\text { aggregate }\end{array}$ & $\begin{array}{l}\text { diffuse, } \\
\text { diffuse-in- } \\
\text { aggregate } \\
\text { and scanty }\end{array}$ & $\begin{array}{c}\text { diffuse, } \\
\text { diffuse-in- } \\
\text { aggregate } \\
\text { and rarely } \\
\text { scanty }\end{array}$ & $\begin{array}{l}\text { diffuse and } \\
\text { diffuse-in- } \\
\text { aggregate }\end{array}$ & $\begin{array}{c}\text { diffuse, } \\
\text { diffuse-in- } \\
\text { aggregate } \\
\text { and } \\
\text { vasicentric }\end{array}$ & $\begin{array}{c}\text { diffuse, } \\
\text { diffuse-in- } \\
\text { aggregate } \\
\text { and scanty }\end{array}$ \\
\hline Ray width & $1-3$ & $1-3$ & - & $\begin{array}{l}1-3, \text { large } \\
\text { rays } 4-10 \\
\text { common }\end{array}$ & $\begin{array}{l}\text { Exclusively } \\
\text { uniseriate, } \\
\text { presence of } \\
\text { sheath cells }\end{array}$ & $1-3$ & $\begin{array}{c}1-3 \text {, rarely } \\
4\end{array}$ \\
\hline Rays body & \begin{tabular}{|c|} 
procumbent \\
$2-4$ rows of \\
upright/ \\
square \\
marginal \\
cells
\end{tabular} & $\begin{array}{c}\text { with over } 4 \\
\text { rows }\end{array}$ & $\begin{array}{c}\text { with mostly } \\
2-4 \text { rows or } \\
\text { over } 4\end{array}$ & $\begin{array}{c}\text { with } \\
\text { mostly } 2- \\
4 \text { rows }\end{array}$ & $\begin{array}{c}\text { with one or } \\
\text { mostly } 2-4 \\
\text { rows }\end{array}$ & $\begin{array}{l}\text { with one } \\
\text { row } \\
\text { marginal }\end{array}$ & $\begin{array}{c}\text { with one or } \\
\text { over } 4 \text { rows } \\
\text { marginal }\end{array}$ \\
\hline
\end{tabular}

From Table 2, the west of Giza Pyramids wood specimen is clearly different from these six African fossil species. It is also less likely that the present specimen, belongs to any of the remaining species (Canthiumoxylon neyveliensis, Naucleoxylon spectabile and Rubioxylon naucleoides) which exist in continents other than Africa and are or probably are of different ages (Table 1). The present specimen, therefore most probably represents a genus or at least a species that is new to science, however, in the absence of RLS it cannot be perfectly diagnosed or even named. It is hoped to come across this type of wood in a future excursion.

Egypt. J. Bot. 56, No. 3 (2016) 


\section{Discussion}

The main wood features of the present Rubiaceae specimen are: indistinct growth rings, diffuse-porosity, often multiples of vessels, high vessel frequency, diffuse parenchyma and very thin-walled fibers, indicating non-seasonal cool temperate or more probably high montane tropical palaeoclimate because most of the other fossil wood species known from the study site [Glutoxylon symphonioides (Anacardiaceae), Terminalioxylon edwardsii, T. geinitzii, T. intermedium, T. primigenium (Combretaceae), Ebenoxylon aegyptiacum (Ebenaceae), Detarioxylon aegyptiacum (Fabaceae-Caealpinioideae), Dalbergioxylon dicorynioides (Fabaceae-Faboideae), Tetrapleuroxylon acacieae (Fabaceae-Mimosoideae), Bombacoxylon owenii, (MalvaceaeBombacoideae), Ficoxylon blanckenhornii, F. cretaceum (Moraceae) and Sapindoxylon stromeri (Sapindaceae) (Schenk, 1883; Stenzel, 1904; Schuster, 1910; Kräusel, 1939 and Youssef, 1993)] have indistinct growth rings diffuseporous wood, solitary and in multiples vessels, medium to large vessels, simple perforation plates, 5-20 vessels / sq. mm, abundance of axial parenchyma and very thick-walled fibers (Kräusel, 1939; Youssef, 1993; Kamal El-Din, 2002; El-Saadawi \& Kamal El-Din, 2004; El-Saadawi et al., 2011; Kamal El-Din et al. 2015); features that are common in tropical non-seasonal climates (Wheeler \& Baas 1991, 1993; Alves \& Angyalossy-Alfonso 2000, 2002). The presence, in the study area, of Palmoxylon $[P$. aschersoni and P. libycum (Arecaceae) (Kräusel \& Stromer, 1924)] also supports the tropical or subtropical nature of the growth site (see El-Saadawi et al., 2004).

In addition to this, the extant relatives of the sixteen fossil species of the west of Giza Pyramids area i.e. Gluta, Terminalia, Detarium, Dalbergia, Tetrapleura, Bombax, Ficus, Ebenaceae, Rubiaceae, Sapindaceae and Arecaceae all have a large number (a few have a small number) of species living today mainly in the tropics (Mabberley, 1987). Furthermore, the families: Ebenaceae, Fabaceae-Caesalpinioideae, Malvaceae sensu lato, Rubiaceae, Sapindaceae and Arecaeae which are represented by fossil wood in the present study site, dominate with some other families today, in the African forest communities (Jacobs, 2004), thus indicating essentially forest biomes for the present study site or more precisely for the original site of growth of these trees and palms.

Acknowledgments: Thanks are due to Prof. Dr. Rifaat Osman (Geology Department, Faculty of Science, Benha University) for guiding the excursion to the study area and kind help with the collection of the fossil wood specimens. Thanks are also due to Prof. Dr. Magdy Al-Sersy (Geography Department, Women's College for Science, Arts and Education, Ain Shams University) for 
kind help with the map and to Mr. Mohamed Farag (Botany Department, Faculty of Science, Ain Shams University) for kind help with the digital plate.

\section{References}

Alves, E. and Angyalossy-Alfonso, V. (2000) Ecological trends in the wood anatomy of some Brazilian species. 1. Growth rings and vessels. IAWA J., 21, 3-30.

Alves, E. and Angyalossy-Alfonso, V. (2002) Ecological trends in the wood anatomy of some Brazilian species. 2. Axial parenchyma, rays and fibers. IAWA J., 23 , 391-418.

Andrews, H.N. (1961) "Studies in Palaeobotany". Wiley, New York and London, pp. 1487.

APG III (2009) An update of the Angiosperm Phylogeny Group classification for the orders and families of flowering plants. Bot. J. Linn. Soc., 161, 105-121.

Chandler, M.E. (1954) Some Upper Cretaceous and Eocene fruits from Egypt. Bull. Brit. Mus. (N.H), Geol., 2, 149-187.

Dechamps, R. (1976) Résultats préliminaires de l'étude des bois fossiles de la basse vallée de l'Omo (Ethiopie sud occidentale). Rapp. Ann. Mus. Roy. Afr. Cent., Tervuren, Dépt. Géol. Min., (1975), 59-65. (Cited from Gregory et al., 2009, cited below)

Dupéron-Laudoueneix, M. and Dupéron, J. (1995) Inventory of Mesozoic and Cenozoic woods from equatorial and north equatorial Africa. Rev. Palaebot. Palynol., 84, 439-480.

El-Saadawi, W.E. and Kamal El-Din, M.M. (2004) Terminalioxylon species from Gebel Qatrani Formation at Widan El-Faras, Fayum, Egypt. Taeckholmia, 24, 63-78.

El-Saadawi, W.E., Kamal El-Din, M.M., Attia, Y. and El-Faramawi, M.W. (2011) The wood flora of the Cairo Petrified Forest, with five Paleogene new legume records for Egypt. Rev. Palaeobot. Palynol., 167,184-195.

El-Saadawi, W., Kamal El-Din, M.M., Wheeler, E., Osman, R., El-Faramawi, M.W. and El-Noamani, Z. (2014) Early Miocene woods of Egypt. IAWA J., 35, 35-50.

Gregory, M., Poole, I. and Wheeler, E.A. (2009) Fossil dicot wood names an annotated list with full bibliography. IAWA J., supplement 6, 1-220.

http://insidewood.lib.ncsu.edu/description (2016) Online search of fossil and modern wood data base available at inside wood home page.

IAWA Committee (1989) IAWA list of microscopic features for hardwood identification. IAWA Bull. n.s., 10, 219-332.

Issawi, B., EL-Hinnawi, M., Francis, M. and Mazhar, A. (1999) The Phanerozoic Geology of Egypt a Geodynamic Approach. The Egyptian Geological Survey: Special Publication, 76, 1-462.

Egypt. J. Bot. 56, No. 3 (2016) 
Jacobs, B.F. (2004) Palaeobotanical studies from tropical Africa: relevance to the evolution of forest, woodland and savannah biomes. Phil. Trans. R. Soc. Lond. B, 359, $1573-1583$.

Jansen, S., Robbrecht, E., Beeckman, H. and Smets, E. (2002) A survey of the systematic wood anatomy of the Rubiaceae. IAWA J., 23, 1-67.

Kamal El-Din, M.M. (2002) Bombacoxylon owenii (Carr.) Gottwald from Gebel Shabraweet, Eastern Desert, Egypt. Taeckholmia, 22, 91-99.

Kamal El-Din, M.M., Darwish, M. and El-Saadawi, W. (2015) Novelties on miocene woods from egypt with a summary on african fossil woods of fabaceae, malvaceae and dipterocarpaceae. Palaeontographica B, vol. 292,173-199.

Koek-Noorman, J. (1977) Systematische holzanatomie einiger rubiaceen. Ber. Deut. Bot. Ges., 90,183-190.

Koeniguer, J. (1975) Expéditions paléontologiques au Tchad. I. Les bois plio-quarternaires du Nord-Tcad (Kolinga, Koro-Toro, Angamma). Ann. Paleont., Invert., 61, $177-214$.

Kräusel, R. (1939) Ergebnisse der Forschungsreisen Prof. E. Stromers in den Wüsten Ägyptens, IV. Die fossilen Floren Ägyptens: 3. Die Fossilen Pflanzen Ägyptens. EL Abh. Bayer. Akad. Wiss., Math. Nat. Abt.(N. F.), 47, 1-140.

Kräusel R and Stromer E. 1924. Ergebnisse der Forschungsreisen Prof. E. Stromers in den Wüsten Ägyptens, IV. Die fossilen Floren Ägyptens: 1-3. A-C. Abh. Bayer. Akad. Wiss. Math. Nat. Abt., 30, 1-48.

Mabberley, D.J. (1987) "The plant-book. A Portable Dictionary of the Higher PLants". Cambridge University Press, Cambridge ,pp. 1-706.

Metcalfe, C.R. and Chalk, L. (1950) "Anatomy of Dicotyledons". 2 Volumes. Clarendon Press, Oxford, vol. 1: 1724, vol. 2, 725-1500.

Said, R. (1962) "The geology of Egypt". Elsevier, Amsterdam.

Said, R. (1971) Explanatory notes to accompany the geological map of Egypt. The geological Survey of Egypt paper no., 56, 1-123.

Schenk, A. (1883) Fossile Hölzer. Palaeontogr., 30, 1-19.

Schuster, J. (1910) Über Nicolien und Nicolien ähnlichen Hölzer. K. Sven. Vetenskapsakad. Handl., 45, 1-18.

Stenzel, K. G. (1904) Fossile Palmenhölzer. Beit. Z. Pal. u. Geol. Österr. Ung. u. d. Orients Bd., 16, 107-287. 
Wheeler, E.A. and Baas, P. (1991) A survey of the fossil record for dicotyledonous wood and its significance for evolutionary and ecological wood anatomy. IAWA Bull., n. s., 12, 271-332.

Wheeler, E.A. and Baas, P. (1993) The potentials and limitations of dicotyledonous wood for climatic reconstruction. Paleobiology, 19, 487-498.

Youssef, S.G. (1993) Studies on some Egyptian fossil woods. Ph.D. Thesis, Bot. Dept., Fac. of Sci., Zagazig Univ., Benha, Egypt, pp. 1-153.

تم وصف عينـة خشب ذات فلقتين من عصر الميوسين المبكر من تكوين جبل

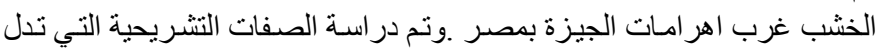

علي انتمائها لفصيلة Rubiaceae مع التعليق علي توزيع هذه الفئمة الفصيلة في العالم

وخاصة افريقيا . 